PiOTR SiŁKA

Polska Akademia Nauk

Warszawa

\title{
Przyklad indeksu potencjału innowacyjnego dla wybranych miast Polski
}

Szeroko pojęta innowacyjność jest obecnie jedną z bardziej popularnych koncepcji w geografii ekonomicznej. W literaturze naukowej znajdujemy bardzo wiele propozycji definicji innowacji, a co za tym idzie - zagadnień z nią powiązanych, stąd warto zwrócić szczególną uwagę na próby systematyzacji wiedzy na ten temat. Jednej z takich prób dokonali autorzy Marinova i Philimore (2003), wyróżniając następujące modele innowacji: idea „czarnej skrzynki”, modele lineralne, modele interaktywne, modele systemowe, modele ewolucyjne, modele środowiska innowacyjnego. Każdy z tych modeli nie tylko przynosił nowy sposób ujęcia tematu, ale także próby wyjaśnienia, co wpływa na innowacyjność poszczególnych układów terytorialnych. W pierwszym modelu brano pod uwage jedynie środki finansowe zainwestowane w badania jednostek badawczo-rozwojowych, w ostatnich zaś dominują ujęcia kompleksowe, jak np. koncepcja regionalnych systemów innowacji. Trudno jednak w opracowaniach podejmujących tę tematykę znaleźć konkretne definicje dotyczące potencjału innowacyjnego, który intuicyjne można określić jako zespół czynników sprzyjających innowacyjności. W polskiej literaturze naukowej takim wyjątkiem jest artykuł R. Guzika (2004, s. 1), w którym określa on potencjał innowacyjny jako ,zdolność do wytwarzania dyfuzji i konsumpcji innowacji przez badania jednostki”. Częściej wymienia się elementy potencjału innowacyjnego, którymi są po prostu czynniki społeczno-ekonomiczne. Według Koschatzkiego (1997) czynniki te to: podaż - dostawcy technologii, usługi innowacyjne, strategie i polityki, otoczenie regionalne, relacje pomiędzy firmami, stosunki wewnętrzne w firmie, działania w zakresie $\mathrm{B}+\mathrm{R}$. W związku z powyższym autor niniejszego artykułu na użytek własnych analiz proponuje następującą definicję potencjału innowacyjnego: jest to zespół cech danego układu terytorialnego, sprzyjających działalności innowacyjnej, podejmowanej przez podmioty gospodarcze w tym układzie. Dokonując operacjonalizacji tego pojęcia autor wykorzystał literaturę dotyczącą wskaźników innowacyjności. Jednym z najważniejszych jest indeks innowacyjności w podręcznikach Oslo Manual, wykorzystywany m.in. przez Komisję Europejską. Jednakże w wielu przypadkach, gdy konstruowane są inne sumaryczne wskaźniki, część cech, jak np. liczba zatrudnionych, jest używana jako miernik zarówno w przypadku analizy potencjału innowacyjnego, jak i innowacyjności. Autor, by uniknąć takich nieporozumień przyjął, że w przypadku pomiaru potencjału innowacyjnego będą brane pod uwagę wskaźniki tzw. statystyki wkładu (input statistics) w odróżnieniu od stosowanych także tzw. statystyk efektów (output and impact statistics), które w opinii autora mogą być faktycznie włączone w sumaryczny wskaźnik innowacyjności. 
W polskiej literaturze jest wiele przykładów analiz z wykorzystaniem wskaźników innowacyjności. Badania takie dla całej Polski opublikowali m.in. Domański (1979), Baczko (2007), Kukliński (2004), Weresa (2001), Żołnierski (2008), Stawasz (1999), Wojnicka (2001), Lis (2007). Analizy w układzie województw podejmowali m.in. Chmielewski i inni (2001), Stryjakiewicz (2002), Olechnicka (2007), Markowska (2008), a analizy powiatów m.in. Guzik (2004), Reichel (2006). W małym zakresie podejmowane były także analizy polskich miast. Stąd autor skierował swoje zainteresowania badawcze w tym kierunku. Na podstawie powyższego przeglądu literatury autor proponuje indeks potencjału innowacyjnego dla miast powiatowych w Polsce.

\section{METODOLOGIA I PREZENTACJA WYBRANYCH WSKAŹNIKÓW}

Poniższa analiza oparta jest na pięciu wskaźnikach. Autor jest świadom, że można włączyć do indeksu więcej wskaźników, co zapewne jeszcze lepiej zobrazuje potencjał innowacyjny analizowanych miast. Jednakże w wyniku trudności w pozyskaniu danych z Głównego Urzędu Statystycznego na potrzeby niniejszego artykuły zostało przyjętych pięć następujących cech:

- liczba absolwentów/liczba mieszkańców w wieku produkcyjnym,

- liczba instytucji proinnowacyjnych/liczba podmiotów gospodarczych,

- zgłoszenia do urzędu patentowego/liczba mieszkańców w wieku produkcyjnym,

- instytucje realizujące projekty ramowe/liczba mieszkańców w wieku produkcyjnym,

- przedsiębiorcy w wybranych branżach/liczba mieszkańców w wieku produkcyjnym.

Dane te zostały opracowane dla 65 miast na prawach powiatu w trzech przedziałach czasowych: 2000, 2004, 2008. Na kolejnym etapie analizy zastosowano standaryzację zmiennych za pomocą Z-score. Następnie został skonstruowany sumaryczny wskaźnik (indeks) potencjału innowacyjnego (IPi) z pomocą wskaźnika Perkala z zastosowaniem wag (największe wagi przypisano zgłoszeniom do urzędu patentowego oraz instytucjom realizującym projekty ramowe).

Poszczególne wskaźniki wykorzystane w stworzeniu indeksu potencjału innowacyjnego są interesujące jako poszczególne cechy. Dlatego zostały one bliżej opisane, choć w ujęciu bezwzględnym.

Pierwszym wskaźnikiem wziętym pod uwagę jest liczba instytucji proinnowacyjnych. W tym celu wykorzystano dane znajdujące się w raportach Stowarzyszenia Organizatorów Ośrodków Innowacji i Przedsiębiorczości w Polsce (SOOIiPP). Do analizy wzięto pod uwagę tylko wybrane typy instytucji działających lokalnie, takich jak: parki naukowo-technologiczne, inkubatory technologiczne, inkubatory przedsiębiorczości, inkubatory akademickie, centra transferu technologii. Perspektywa członkostwa w EU i dostęp do funduszy strukturalnych w szczególny sposób zdynamizowały rozwój tych instytucji wsparcia. W roku 2000 było ich 25, zaś w roku 2008 już ponad 130 - najwięcej w Warszawie, Krakowie i Poznaniu (ryc. 1). 


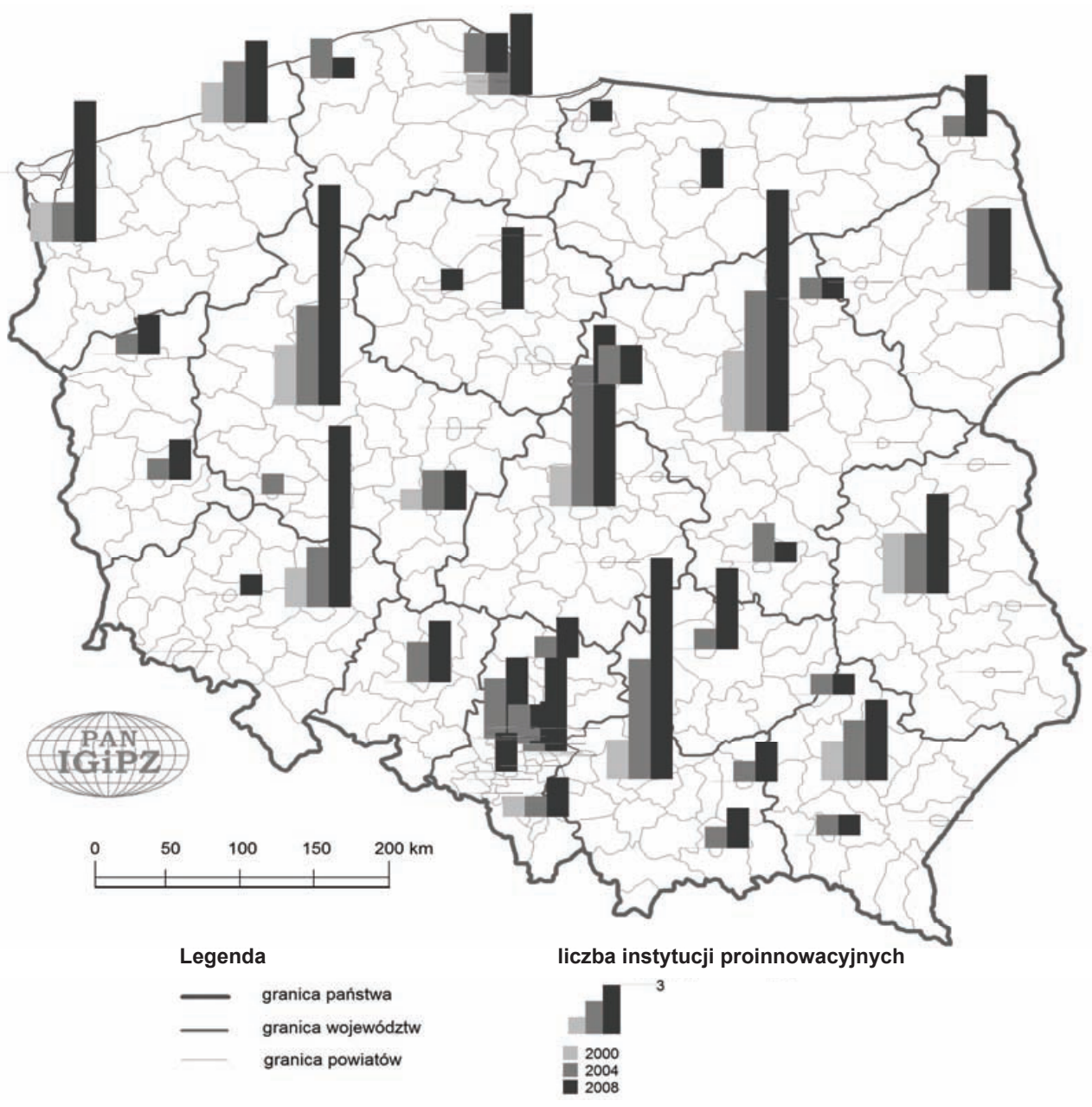

Ryc. 1. Instytucje proinnowacyjne $\mathrm{w}$ analizowanych miastach

Źródło: Opracowanie własne na podstawie danych SOOIiPP

Kolejny wskaźnik wzięty pod uwagę to liczba absolwentów, która dla całej Polski systematycznie rośnie od 1999 roku. W ostatnim notowanym roku (2008) mury wyższych uczelni opuściło z sukcesem ponad 419 tysięcy studentów. W niektórych miastach wzrost w porównaniu z 2000 jest imponujący: Gorzów Wielkopolski (816\%), Legnica (553\%), Konin (392\%), Biała Podlaska (264\%). Największą liczbę absolwentów w analizowanym okresie zanotowano w Warszawie - prawie 50 tys., następnie w Krakowie - 28 tys., Wrocławiu i Poznaniu - po 25 tys., Łodzi - 22 tys., Lublinie - 18 tys. (ryc. 2).

Trzecim wskaźnikiem branym pod uwage jest liczba zarejestrowanych przedsiębiorców w trzech działach PKD: Przetwórstwo przemysłowe - C, Informacja i komunikacja - J, Działalność profesjonalna, naukowa i techniczna - M. Zauważyć można, że w większości miast nastąpił lekki wzrost liczby wziętych pod uwage podmiotów gospodarczych. 
Największe wzrosty zanotowano w Warszawie (66\%), Jaworznie (53\%), Rudzie Śląskiej (53\%), Świętochłowicach (52\%), Poznaniu (51\%). Niewielkie spadki z kolei w Elblągu oraz Chełmie (ryc. 3).

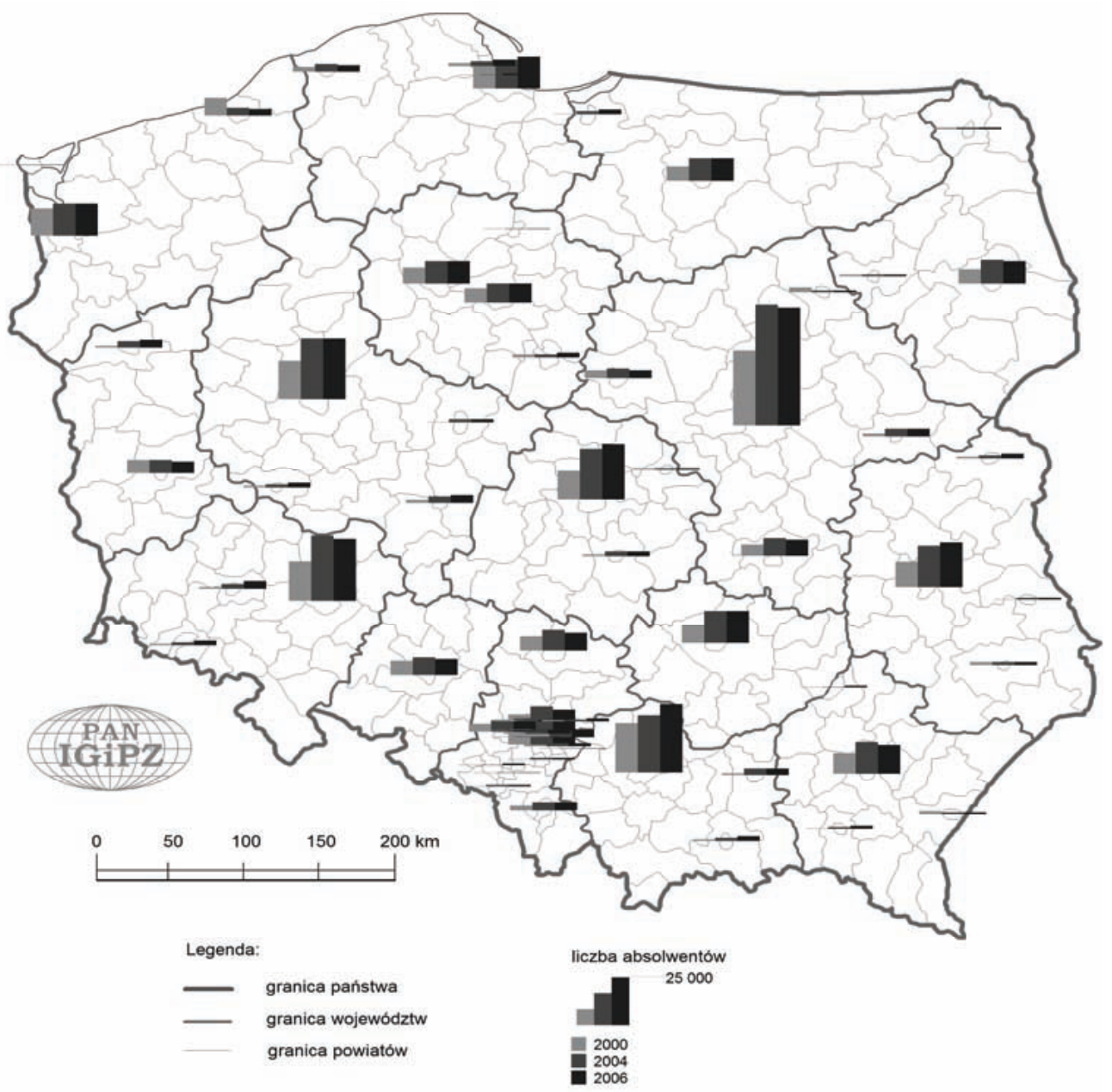

Ryc. 2. Absolwenci w analizowanych miastach

Źródło: Opracowanie własne na podstawie danych GUS

Kolejny wskaźnik dotyczy liczby zgłoszenia wynalazków oraz wzorów przemysłowych do Urzędu Patentowego Rzeczypospolitej Polskiej (UPRP). Zastosowano metodę zliczania całkowitego w trzech okresach: 1998-2000, 2001-2004, 2005-2007. Trzeba tutaj wyjaśnić, dlaczego taki wskaźnik zostały użyty do stworzenia indeksu potencjału innowacyjnego, podczas gdy zazwyczaj jest on wykorzystywany w analizach innowacyjności. 


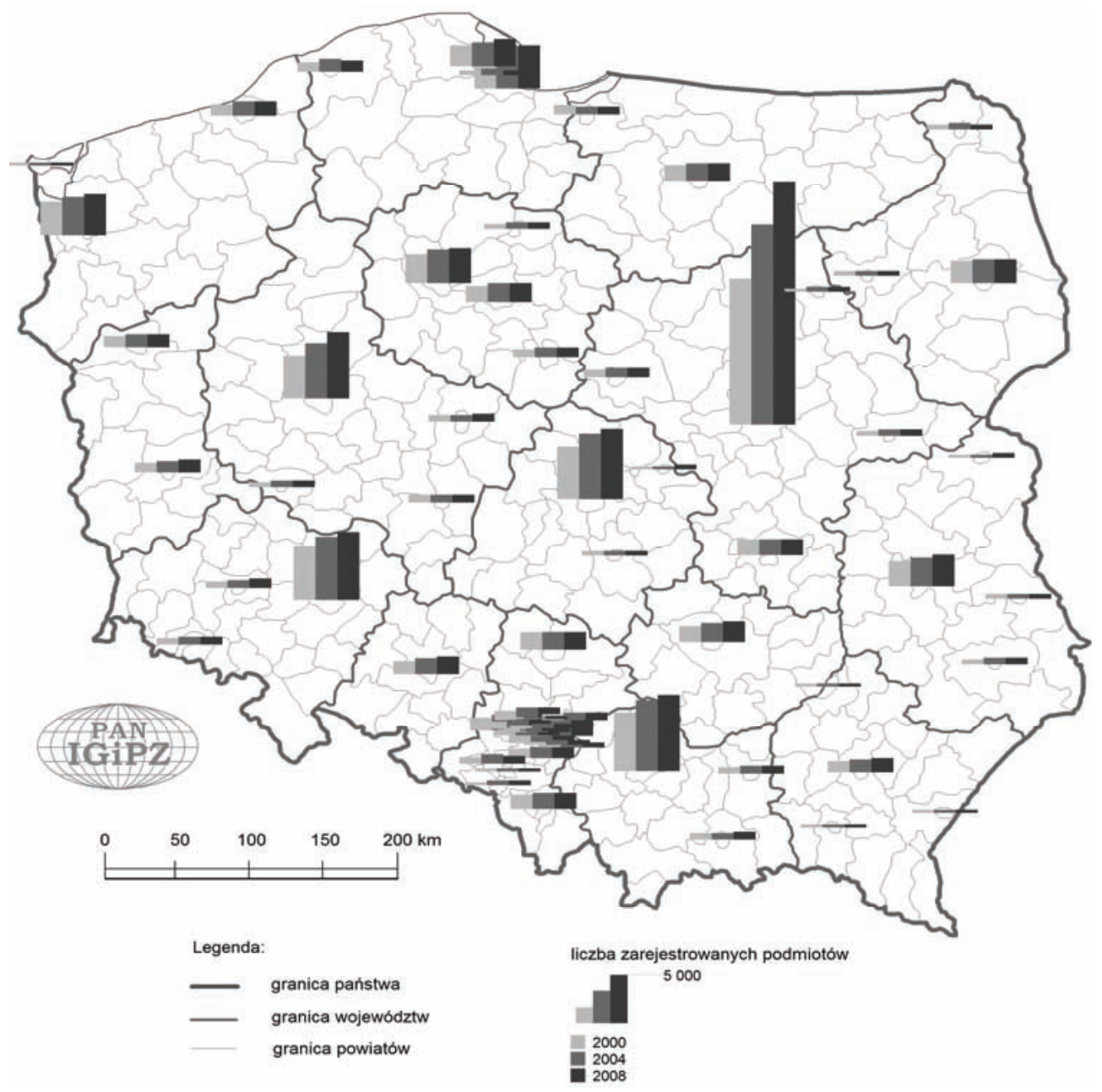

Ryc. 3. Wybrane podmioty gospodarcze $\mathrm{w}$ analizowanych miastach

Źródło: Opracowanie własne na podstawie danych GUS

Otóż, zgodnie z coraz częstszymi uwagami w literaturze, trudno wynalazczość utożsamiać bezpośrednio z innowacyjnością. Tym bardziej w Polsce, gdy tylko 7\% przedsiębiorców zgłasza się do UPRP, często tylko raz, bo średnio na decyzję czeka się ponad 3 lata, co skutecznie zniechęca ich do kolejnych prób. Dodać należy także, że wnioski te nie podlegają ocenie merytorycznej pod względem przydatności na rynku prezentowanych wynalazków. Dla analizowanego okresu zanotowano ponad 22 tysiące zgłoszeń, w tym ponad 5 tysięcy z Warszawy oraz po około 2 tysięcy z Wrocławia i Krakowa. Z największych ośrodków tylko Wrocław miał minimalny wzrost, w większości zaś miast liczba ta zmniejszała się. W wyniku porównania 3 okresów tylko 6 miast osiągnęło wzrost liczby zgłoszeń. Największe spadki nastąpiły w miastach Tarnobrzeg, Grudziądz, Włocławek, Piekary Śląskie (ryc. 4). 


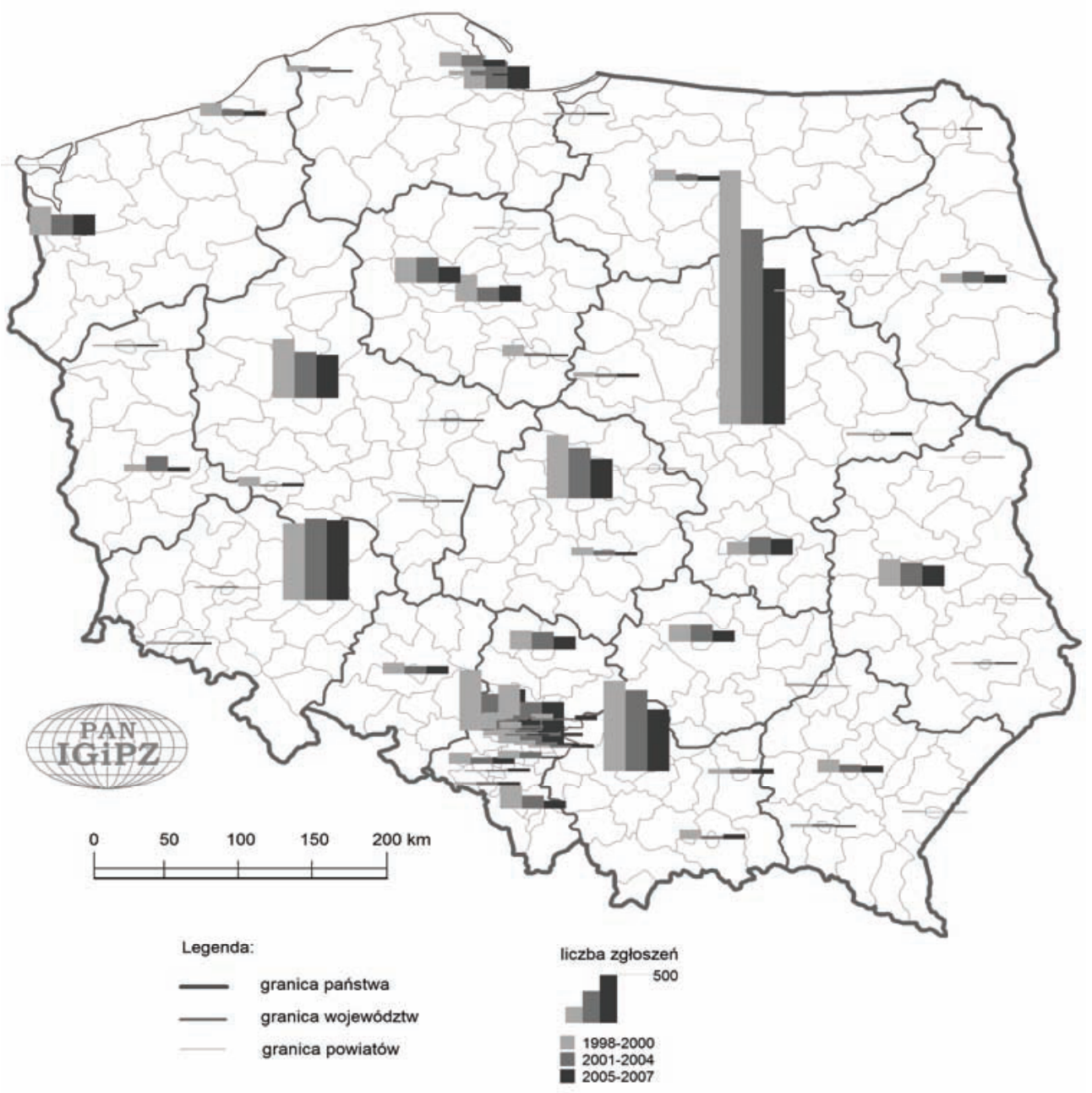

Ryc. 4. Zgłoszenia wynalazków i wzorów przemysłowych w analizowanych miastach

Źródło: Opracowanie własne na podstawie danych UPRP

Ostatnim wskaźnikiem wykorzystanym w analizie jest liczba instytucji biorących udział w projektach finansowych w ramach IV-VII Programów Ramowych na podstawie bazy Cordis. Projekty przypisano do poszczególnych okresów, biorąc pod uwagę datę rozpoczęcia projektu. Zastosowano metodę zliczania całkowitego w trzech okresach: 1998-2000, 20012004, 2005-2007. W analizowanym okresie ponad 3500 instytucji brało udział w realizacji tego typu projektów, z czego ponad 1400 z Warszawy oraz 500 z Krakowa. Porównując pierwszy i trzeci analizowany okres, wśród największych ośrodków duży postęp uczynił Poznań (345\%) (ryc. 5).

Następnie, w celu prezentacji indeksu innowacyjności, podzielono analizowane miasta na trzy grupy. Pierwszy zbiór to miasta na prawach powiatu zaliczane do tzw. Europejskich Metropolitalnych Obszarów Wzrostu (MEGA), wyróżnionych w ramach programów 
ESPON. Są to 22 miasta, traktowane jako 7 ośrodków miejskich: Warszawa, Kraków, Łódź, Poznań, Wrocław, Sopot, Gdynia, Gdańsk, czyli Trójmiasto, oraz miasta należące do Konurbacji Górnośląskiej.

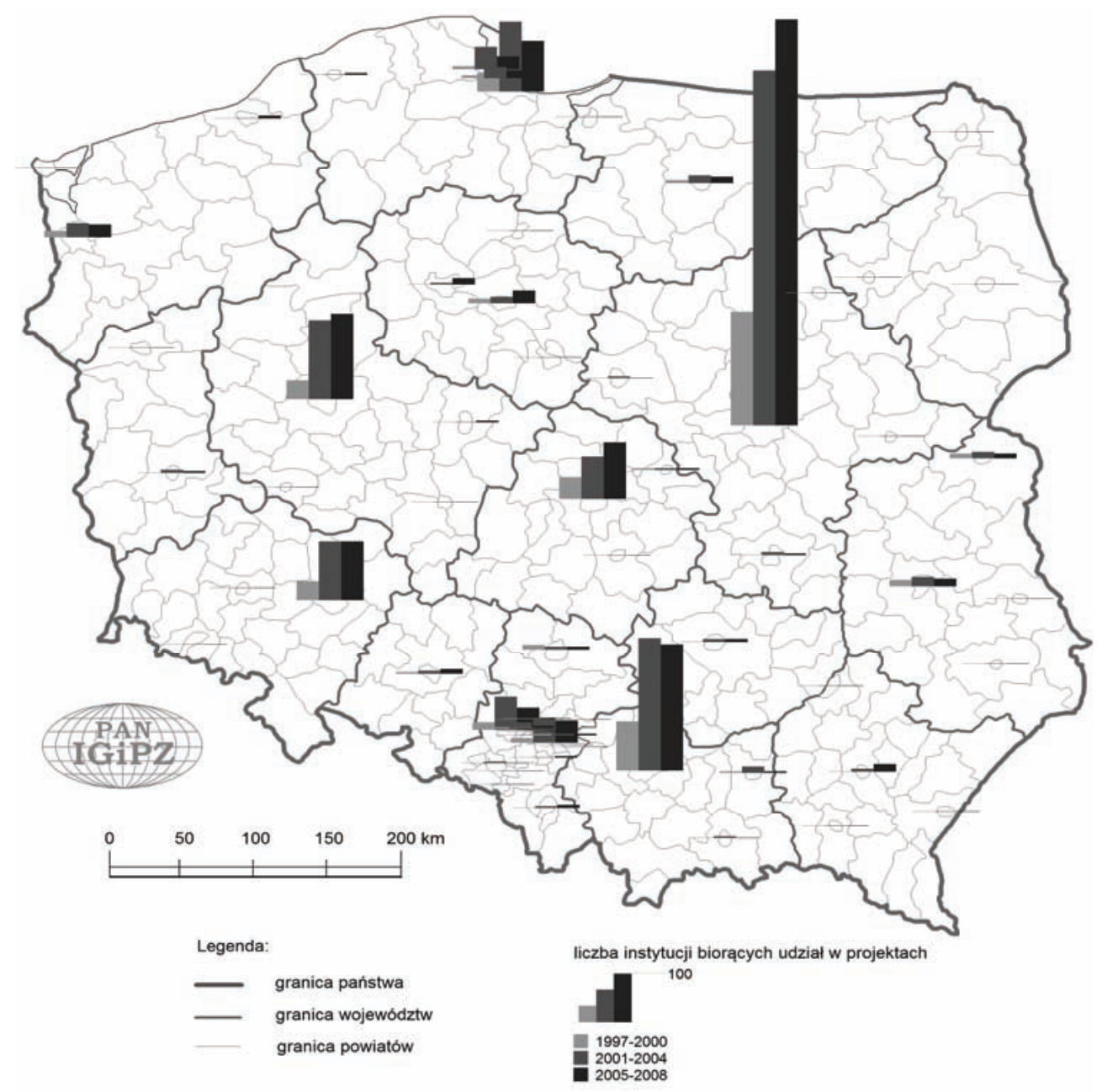

Ryc. 5. Instytucje biorące udział w projektach ramowych w analizowanych miastach

Źródło: Opracowanie własne na podstawie danych CORDIS

Pozostałe miasta na prawach powiatu zostały podzielona na dwie klasy pod względem liczby ludności oraz podmiotów gospodarczych w roku 2008. Podział ten nastapił za pomocą metody „naturalnej przerwy”. Miasta, które znalazły się w pierwszej klasie wymienionych wyżej cech lub też pełnią funkcję administracyjną szczebla wojewódzkiego (niezależnie od tego, czy jest to siedziba wojewody, czy Urzędu Marszałkowskiego) zostały zaliczone do drugiej grupy, liczącej łącznie 15 miast (Białystok, Bielsko-Biała, Bydgoszcz, Częstochowa, 
Gorzów Wielkopolski, Kielce, Koszalin, Lublin, Olsztyn, Opole, Rzeszów, Szczecin, Radom, Toruń, Zielona).

Ostatnia grupa to pozostałe miasta na prawach powiatu (Biała Podlaska, Chełm, Elbląg, Grudziądz, Jastrzębia Góra, Jelenia Góra, Kalisz, Konin, Krosno, Legnica, Leszno, Łomża, Nowy Sącz, Ostrołęka, Piotrków Trybunalski, Przemyśl, Płock, Rybnik, Siedlce, Skierniewice, Suwałki, Słupsk, Świnoujście, Tarnobrzeg, Tarnów, Włocławek, Zamość, Żory) - łącznie 28 miast.

\section{WYNIKI ANALIZY}

W ramach pierwszej grupy miast niepodważalna jest pozycja stolicy na pierwszym miejscu. Zaskakujący może być spadek pozycji Krakowa w ciągu 8 lat. Mimo to, że zanotował on wzrost indeksu, to jednak nie tak duży jak ośrodek wrocławski i poznański, dlatego spadł z drugiej pozycji na czwartą. Tylko ośrodek trójmiejski zanotował spadek wskaźnika sumarycznego, mimo to zachował 5 pozycję (tab. 1).

Tab. 1. Indeks potencjału innowacyjnego (IPI) w ośrodkach MEGA

\begin{tabular}{|l|c|c|c|c|c|c|}
\hline \multicolumn{1}{|c|}{ Miasto } & $\begin{array}{c}\text { IPI } \\
\text { w 2000 r. }\end{array}$ & $\begin{array}{c}\text { Ranga } \\
\text { w } 2000 \mathrm{r} .\end{array}$ & $\begin{array}{c}\text { IPI } \\
\text { w 2004 r. }\end{array}$ & $\begin{array}{c}\text { Ranga } \\
\text { w 2004 r. }\end{array}$ & $\begin{array}{c}\text { IPI } \\
\text { w 2008 r. }\end{array}$ & $\begin{array}{c}\text { Ranga } \\
\text { w 2008 r. }\end{array}$ \\
\hline Warszawa & 0,28 & 1 & 0,32 & 1 & 0,37 & 1 \\
\hline Kraków & 0,21 & 2 & 0,23 & 3 & 0,23 & 4 \\
\hline Wrocław & 0,18 & 3 & 0,23 & 2 & 0,28 & 2 \\
\hline Poznań & 0,15 & 4 & 0,18 & 5 & 0,27 & 3 \\
\hline Trójmiasto & 0,15 & 5 & 0,19 & 4 & 0,14 & 5 \\
\hline Łódź & 0,06 & 6 & 0,08 & 6 & 0,11 & 6 \\
\hline GOP & $-0,08$ & 7 & $-0,07$ & 7 & $-0,07$ & 7 \\
\hline
\end{tabular}

Należy także zwrócić uwagę, iż w ramach aglomeracji GOP-u miastem posiadającym największy potencjał stworzonego wskaźnika są Gliwice, zaś w aglomeracji trójmiejskiej - Sopot.

W ramach drugiej grupy miast na pierwsze miejsce pod względem analizowanego potencjału wysunęło się Opole, które wyprzedziło inne znaczące miasta, takie jak Lublin, Rzeszów czy Białystok. Zawdzięcza to przede wszystkim dużej liczbie zgłoszeń do Urzędu Patentowego (7,5 wynalazków na 10 tys. mieszkańców w wieku produkcyjnym, podczas gdy Rzeszów zaledwie 4,5 zgłoszeń, a Białystok 3,5), a także znaczącej liczbie podmiotów gospodarczych w analizowanych działach (165 na 10 tys. mieszkańców w wieku produkcyjnym, podczas gdy w Lublinie 125, a w Rzeszowie 107 podmiotów). Przypadek Koszalina wymaga także odrębnego wyjaśnienia, bo sumaryczny wskaźnik zanotował bardzo duży spadek. Otóż jest to spowodowane trzykrotnie mniejszą liczbą absolwentów, ponaddwukrotnie mniejszą liczbą zgłoszeń do UPRP, a także bardzo małym wzrostem w przypadku instytucji czy realizowanych projektów ramowych w porównaniu z innymi czołowymi ośrodkami w tej 
grupie miast. Największy postęp w ciągu 8 lat zrobiły Kielce (z 10 na 4 miejsce) oraz Toruń (z 6 na 3 miejsce). Spadki zanotowały: Bielsko-Biała (6 miejsc), Częstochowa i Rzeszów (3 miejsca). $Z$ ośrodków na początku zestawienia największy wzrost indeksu zanotowały Kielce, Opole, Toruń, zaś z końca Gorzów Wielkopolski i Radom (tab. 2).

Tab. 2. Indeks potencjału innowacyjnego (IPI) w ośrodkach regionalnych

\begin{tabular}{|l|c|c|c|c|c|c|}
\hline \multicolumn{1}{|c|}{ Miasto } & $\begin{array}{c}\text { IPI } \\
\text { w 2000 r. }\end{array}$ & $\begin{array}{c}\text { Ranga } \\
\text { w } 2000 \text { r. }\end{array}$ & $\begin{array}{c}\text { IPI } \\
\text { w } 2004 \text { r. }\end{array}$ & $\begin{array}{c}\text { Ranga } \\
\text { w 2004 r. }\end{array}$ & $\begin{array}{c}\text { IPI } \\
\text { w 2008 r. }\end{array}$ & $\begin{array}{c}\text { Ranga } \\
\text { w 2008 r. }\end{array}$ \\
\hline Opole & 0,16 & 3 & 0,20 & 2 & 0,23 & 1 \\
\hline Koszalin & 0,36 & 1 & 0,21 & 1 & 0,20 & 2 \\
\hline Toruń & 0,12 & 6 & 0,05 & 8 & 0,16 & 3 \\
\hline Kielce & 0,05 & 10 & 0,12 & 5 & 0,13 & 4 \\
\hline Rzeszów & 0,18 & 2 & 0,14 & 4 & 0,12 & 5 \\
\hline Lublin & 0,14 & 5 & 0,07 & 6 & 0,11 & 6 \\
\hline Zielona Góra & 0,06 & 9 & 0,18 & 3 & 0,09 & 7 \\
\hline Szczecin & 0,09 & 8 & 0,04 & 10 & 0,09 & 8 \\
\hline Olsztyn & 0,10 & 7 & 0,05 & 9 & 0,05 & 9 \\
\hline Bielsko-Biała & 0,15 & 4 & 0,07 & 7 & 0,04 & 10 \\
\hline Bydgoszcz & 0,01 & 12 & 0,04 & 12 & 0,03 & 11 \\
\hline Gorzów Wielkopolski & $-0,05$ & 15 & $-0,02$ & 15 & 0,02 & 12 \\
\hline Radom & $-0,02$ & 14 & 0,04 & 11 & 0,01 & 13 \\
\hline Częstochowa & 0,03 & 11 & 0,01 & 14 & 0,00 & 14 \\
\hline Białystok & $-0,01$ & 13 & 0,02 & 13 & $-0,02$ & 15 \\
\hline
\end{tabular}

W trzeciej grupie miast w badanych okresach największy wzrost indeksu zanotowały Tarnów i Suwałki, awansując o ponad 10 miejsc, a także Tarnobrzeg (12 miejsc) i Legnica (9 miejsc). Największe spadki poczyniły zaś: Zamość (12 miejsc), Piotrków Trybunalski (11) i Biała Podlaska (10). Największe wzrosty zauważyć można w przypadku Tarnowa, Krosna i Suwałk, a także - z dołu zestawienia - Jastrzębia Zdroju czy Żor (tab. 3).

Tab. 3. Indeks potencjału innowacyjnego (IPI) w ośrodkach subregionalnych

\begin{tabular}{|l|c|c|c|c|c|c|}
\hline \multicolumn{1}{|c|}{ Miasto } & $\begin{array}{c}\text { IPI } \\
\text { w 2000 r. }\end{array}$ & $\begin{array}{c}\text { Ranga } \\
\text { w 2000 r. }\end{array}$ & $\begin{array}{c}\text { IPI } \\
\text { w 2004 r. }\end{array}$ & $\begin{array}{c}\text { Ranga } \\
\text { w 2004 r. }\end{array}$ & $\begin{array}{c}\text { IPI } \\
\text { w 2008 r. }\end{array}$ & $\begin{array}{c}\text { Ranga } \\
\text { w 2008 r. }\end{array}$ \\
\hline Nowy Sącz & 0,07 & 3 & 0,02 & 4 & 0,09 & 1 \\
\hline Shupsk & 0,09 & 2 & 0,16 & 1 & 0,05 & 2 \\
\hline Leszno & 0,13 & 1 & 0,06 & 2 & 0,03 & 3 \\
\hline Krosno & $-0,04$ & 11 & 0,04 & 3 & 0,02 & 4 \\
\hline
\end{tabular}




\begin{tabular}{|l|c|r|r|r|r|c|}
\hline Tarnów & $-0,07$ & 15 & $-0,01$ & 6 & 0,01 & 5 \\
\hline Kalisz & 0,06 & 4 & $-0,02$ & 8 & $-0,02$ & 6 \\
\hline Suwałki & $-0,08$ & 17 & $-0,02$ & 10 & $-0,02$ & 7 \\
\hline Siedlce & $-0,05$ & 12 & $-0,06$ & 14 & $-0,03$ & 8 \\
\hline Płock & $-0,07$ & 16 & 0,00 & 5 & $-0,04$ & 9 \\
\hline Jelenia Góra & $-0,02$ & 8 & $-0,04$ & 12 & $-0,05$ & 10 \\
\hline Ostrołęka & $-0,06$ & 14 & $-0,02$ & 9 & $-0,05$ & 11 \\
\hline Tarnobrzeg & $-0,11$ & 23 & $-0,02$ & 7 & $-0,06$ & 12 \\
\hline Konin & $-0,06$ & 13 & $-0,03$ & 11 & $-0,06$ & 13 \\
\hline Legnica & $-0,11$ & 22 & $-0,10$ & 17 & $-0,06$ & 14 \\
\hline Rybnik & $-0,11$ & 21 & $-0,11$ & 19 & $-0,07$ & 15 \\
\hline Biała Podlaska & $-0,01$ & 6 & $-0,09$ & 16 & $-0,09$ & 16 \\
\hline Zamość & 0,00 & 5 & $-0,08$ & 15 & $-0,09$ & 17 \\
\hline Piotrków Trybunalski & $-0,01$ & 7 & $-0,04$ & 13 & $-0,09$ & 18 \\
\hline Włocławek & $-0,03$ & 9 & $-0,11$ & 18 & $-0,11$ & 19 \\
\hline Skierniewice & $-0,03$ & 10 & $-0,11$ & 20 & $-0,11$ & 20 \\
\hline Elbląg & $-0,09$ & 19 & $-0,14$ & 22 & $-0,12$ & 21 \\
\hline Łomża & $-0,08$ & 18 & $-0,12$ & 21 & $-0,13$ & 22 \\
\hline Jastrzębie Zdrój & $-0,18$ & 27 & $-0,16$ & 26 & $-0,14$ & 23 \\
\hline Świnoujście & $-0,13$ & 25 & $-0,15$ & 23 & $-0,15$ & 24 \\
\hline Żory & $-0,19$ & 28 & $-0,19$ & 27 & $-0,16$ & 25 \\
\hline Chełm & $-0,10$ & 20 & $-0,16$ & 25 & $-0,16$ & 26 \\
\hline Grudziądz & $-0,13$ & 26 & $-0,15$ & 24 & $-0,17$ & 27 \\
\hline Przemý́l & $-0,13$ & 24 & $-0,20$ & 28 & $-0,19$ & 28 \\
\hline & & & & & & \\
\hline
\end{tabular}

\section{Podsumowanie}

Wśród ośrodków MEGA największy wzrost wskaźnika potencjału innowacyjnego zanotowały Poznań, Wrocław i Warszawa. Tylko w przypadku ośrodka trójmiejskiego nastąpił spadek. Zadziwiający jest spadek Krakowa z 2 na 4 miejsce. Być może to tylko efekt statystyczny, co z pewnością będzie dalej badane przez autora. Wśród drugiej kategorii ośrodków najlepiej radzą sobie Kielce, Gorzów Wielkopolski i Opole, najgorzej zaś Koszalin i Bielsko-Biała. W trzeciej grupie analizowanych miast największy wzrost analizowanego indeksu nastąpił dla Tarnowa, Krosna oraz Tarnobrzegu. Spadek indeksu zanotowano w przypadku Zamościa i Leszna. 
W ramach wszystkich badanych ośrodków tylko 5 w roku 2008 zanotowało wskaźnik potencjału innowacyjnego powyżej średniej, są to: Nowy Sącz, Słupsk, Leszno, Krosno oraz Tarnów. Przeprowadzono także analizę indeksu dla poszczególnych grup miast. Wyniki wskazują, że różnice w potencjale innowacyjnym pogłębiają się, co oznacza ,ucieczkę do przodu" największych miast w stosunku do mniejszych ośrodków.

Prezentowana analiza wskazuje na znaczącą dynamikę wskaźnika potencjału innowacyjnego. Z pewnością należy indeks ten wzbogacić o kolejne wskaźniki cząstkowe, co być może spowoduje większą stabilność miast na kolejnych miejscach w rankingu.

\section{Literatura}

Baczko T., 2007, Raporto innowacyjności gospodarki Polski w 2007 roku, Instytut Nauk Ekonomicznych Polskiej Akademii Nauk, Warszawa

Chmielewski R., Stryjakiewicz T., Twardowska J., Waloszczyk J., 2001, Innowacyjność przemystu $i$ jej zróżnicowanie w układzie wojewódzkim, PAN, Biuletyn Komitetu Przestrzennego Zagospodarowania Kraju, z. 197, Warszawa

Domański R., 1979, Dyfuzja innowacji w skali międzynarodowej, Przegląd Geograficzny, z. 1, IGIPZ PAN, Warszawa

Guzik R., 2004, Przestrzenne zróżnicowanie potencjału innowacyjnego w Polsce, [w:] M. Górzyński, R. Woodward (red.), Innowacyjność polskiej gospodarki. Zeszyty Innowacyjne 2, CASE Centrum Analiz Społeczno-Ekonomicznych, Warszawa, s. 33-36

A. Kukliński, 2004, Gospodarka oparta na wiedzy - kluczowy paradygmat rozwoju Polski XXI wieku, [w:] Globalizacja Warszawy - strategiczny problem XXI wieku, Warszawa

Koshatzky K., 1997, Technology-Based Firms in the Innovation Process, Physica-Verlag, Heidelberg

Lis S. (red.), 2007, Gospodarka Polski na poczatku XXI wieku: innowacyjność i konkurencyjność, Akademia Ekonomiczna w Krakowie, Akademia Świętkorzyska, Akademia Ekonomiczna w Krakowie

Marinova D., Philimore J., 2003, Models of innovation, [w:] L.V. Shavinina (red.), The International Handbook on Innovation, Elsvier, s. 44-53

Markowska M., 2008, Innowacyjność polskich regionów - ujęcie dynamiczne, [w:] K. Miszczak, Z.Przybyła(red.), Nowe paradygmatygospodarkiprzestrzennej, Biuletyn Komitetu Przestrzennego Zagospodarowania Kraju PAN, Warszawa, s. 236

Olechnicka A., 2007, Innowacyjność polskich regionów, metody pomiaru, stanu i tendencje, [w:] G. Gorzelak, A. Tucholska, Rozwój, region, przestrzeń, Ministerstwo Rozwoju Regionalnoego, Warszawa, s. 265-288

Reichel M., 2006, Potencjat innowacyjny Polski poludniowo-wschodniej w strukturach subregionalnych, Państwowa Wyższa Szkoła Zawodowa, Nowy Sącz

Stawasz E., 1999, Innowacja a mała firma, Wydawnictwo Uniwersytetu Łódzkiego, Łódź

Stryjakiewicz T., 2002, Analiza innowacyjności przemystu w ujęciu przestrzennym, [w:] H. Rogacki (red.), Możliwości i ograniczenia zastosowań metod badawczych w geografii społeczno-ekonomicznej i gospodarce przestrzennej, Bogucki Wydawnictwo Naukowe, Poznań, s. 207-215

Wojnicka E., 2001, Regionalne systemy innowacyjne w wybranych państwach UE, Wspólnoty Europejskie, nr 11 (123), IKC, Warszawa

Weresa M.A., 2001, Czynniki i bariery innowacyjności gospodarki, VII Kongres Ekonomistów Polskich, z. 17, Warszawa

Żołnierski A. (red.), 2008, Innowacyjność 2008. Stan innowacyjności, projekty badawcze, metody wspierania, społeczne determinanty, Polska Agencja Rozwoju Przedsiębiorczości, Warszawa 
www.cordis.europa.eu/home_pl.html [01.12.2009]

www.sooipp.org.pl [01.12.2009]

www.stat.gov.pl [01.12.2009]

www.uprp.pl [01.12.2009]

\section{Innovation potential of Polish cities}

Innovation has been a buzz-word in social and economic sciences for over two decades. Nevertheless, the concept of the innovation is one of the most debatable. There are many attempts to create new and better indicators of innovativeness. One of the most known is the European Innovation Scoreboard (EIS), developed by the European Commission and based on the Oslo Manual methodology. The innovation indicators which are used in EIS are assigned to five dimensions and grouped in two main themes: inputs and outputs. Due to the problem of data source, it is hard to analyze output indicators in Poland, especially for cities. It is easier to collect data for the input indicator, which can be called innovation potential. This article presents the aggregate indicator of innovation potential (for years 2000, 2004, 2008) in the biggest cities in Poland, based on five indicators. The analysis shows, apart from interesting changes in the ranking of cities, that the gap between metropolises and other cities is growing.

\section{Mgr Piotr Siłka}

Polska Akademia Nauk

Instytut Geografii i Zagospodarowania Przestrzennego

Warszawa

e-mail: psilka@twarda.pan.pl 